\title{
Multiple Authors and Puzzled Readers in the Historia Augusta
}

The Historia Augusta is for modern scholars a polarizing text. Some regard it with fear and aversion, as bringing down massive interpretive headaches on anyone who tries to use it as a historical source. Others have found it compelling and irresistible as a puzzle. This split reaction is rooted in the text's uncertain authorial status, which calls into question the status of all the truth-claims it contains. We naturally process the authorship question with the mentalities and methodologies of modern philologists or historians seeking a particular kind of factual certainty, but we are not inventing the difficulty: key features of the $H A$ itself present the text's origins as a problem or puzzle. In a volume dedicated to ancient reading practices and mentalities, I want to explore the authorship question, but with a reader-based approach that asks how the text functioned in its original setting, and what its first readers would have made of those features that have created so much controversy among their scholarly posterity centuries later.

The $H A$, to outline the question briefly, is a collection of thirty lives of emperors running from Hadrian (117-138) to Carus (282-283) and his sons. It claims to be the product of six otherwise unknown personages writing in the period roughly 290 330 , who are conventionally referred to as the scriptores. Since the late 1800s, however, a near consensus has developed among modern scholars that it is in fact the product of a single author writing perhaps around the year $400 .^{1}$ This anonymous

The Latin of the $H A$ is cited from Hohl 1971. Translations are my own. The notes of Casaubon and Salmasius are cited ad loc. from Hackius et al. 1671. I am most grateful to the conference organizers and editors for the opportunity to participate in such a stimulating conference and volume, as well as to the anonymous reader and to Antonio Pistellato and David Rohrbacher for their perceptive comments on a draft. Thanks also go to Martin Shedd for permitting me to cite unpublished work. 1 The initial statement of this hypothesis is Dessau 1889, and the best reassertion of it in the face of subsequent debates is White 1967. Pluralist dissenters in recent decades include Lippold 1998; Den Hengst 2002 and Baldwin 2010. Den Hengst in particular places much weight on the computer analysis of Gurney / Gurney 1998. That study, while opaque to the statistically uninitiated, does appear to demonstrate that there are significant differences of vocabulary usage among all six of the sets of lives attributed to the various scriptores. However, the study's authors give no indication that the test is able to distinguish between a genuine multiple-author situation and either (a) one author consciously varying style or (b) one author who incorporates varying amounts of unaltered source material. Most of White et al.'s arguments why the scriptores cannot be who they claim to be (shared fictions, thematic preoccupations, anachronisms etc.), are beyond the scope of the Gurney study and persist regardless of it. The most likely hypothesis is that the statistical results reflect the author's use of different degrees and kinds of source material and fictional documents. A subsequent computer study (Stover / Kestemont 2016) has detected less variation between scriptores but more between the earlier and later lives, consistent with a single author and changing source practices. None of this 
character has fabricated the six names, along with a large proportion of the content, including significant characters, earlier authors and documents. Modern scholars have wanted to deduce as much as they can about the personal characteristics and motivation of this presumed author, the better to use his work as a historical source. In posing the question "what kind of text is this and what can we do with it" one cannot help further asking "who on earth would come up with such a thing?" Was the $H A$ author a deceptive forger, a religious or political ideologue, a literary joker, or what? Thus over the last hundred and more years a great deal of learned and rigorous scholarship has treated the $H A$ as a puzzle to which the solution is an author. While this work has much to say about the intended audience of the $H A$ based on the text's religious, ideological or social self-positioning, the text's formal literary characteristics have been considered almost entirely with reference to the author's intentions, be they deceitful, mischievous or propagandistic.

My aim here is to complement these approaches, by concentrating less on the text the $H A$ "actually" is than on the text it claims to be, and how ancient readers approached its claims. In particular, I will examine the fiction of multiple authorship and what readers would have made of it. Modern readers can and do dispense with the scriptores very quickly as an obstacle to interpretive clarity. All of the self-referential passages I will be analyzing have been gone over in minute detail, but have typically been read as the voice of a single author/narrator describing his own practices, truthfully or otherwise. ${ }^{2}$ This is natural enough because the issues raised in the various passages turn out to be relatively uniform, and one can indeed speak meaningfully of a single mentality and rhetorical stance common to most if not all of the

is to say the authorship issue is entirely simple. Several scholars have not unreasonably asked whether, given the amount of unaltered source material, one should speak not of a single author but of a redactor of a multi-layered corpus. But this is a separate question, and one of degree. What is crucial for our purposes is that the $H A$ creates a specific scenario for its own creation, based on a series of claims that must be either true or false. Arguments from anachronism and thematic unity demonstrate that all or most of the claims cannot be true, and that the scenario as a whole is a fiction. Whoever is responsible for the $H A$, it cannot be, as the text asserts, six otherwise unknown contemporaries who just happened to write the same uniquely bizarre kind of biography. On the dating question, it suffices for my purposes to place the $H A$ after 390, thus certainly later than Victor, Eutropius and Festus and probably later than Ammianus. Cameron 2011, 743-782 argues instead for a date in the 360 s to 380s. Cases have recently been made for dates later in the 400s or into the 500s, see Mastandrea 2011; Savino 2017.

2 In what follows, I will be referring to the hypothesized $H A$ author in the masculine, partly because using "they" would confuse the issue of unitary or multiple authorship. This implies no claims about the historical author, but the implied author is constructed within discourses (both in the fifth century and the twentieth) that would have assumed he was a man, and this is reinforced by the scriptores' names and grammatically masculine first-person statements, and the prefatory asides in which they imagine literary activity taking place in a male homosocial environment (e.g. Trig. 31.10 on women pretenders to the throne). 
first-person statements. ${ }^{3}$ Many scholars have found the six scriptores only superficially differentiated as literary personae, and have seen them as an afterthought carelessly imposed on a largely finished work that had originally had a single narrative voice. $^{4}$

Nonetheless, any interpretation that takes ancient readers as its starting point must consider what starting point those readers took. They could not ignore the scriptores, at least at the outset. Rather it is above all through the fiction of the scriptores that they initially encountered the $H A$, and their first moves would have been to engage with that fiction, to ask a series of questions to which modern readers find the answers in scholarly introductions before they begin on the text. This is not to say they all credulously accepted the answers the text explicitly provides. Doubtless some did, and never questioned that Spartianus, Lampridius and so on were really who they claimed to be. Others picked up on the same cues (or different cues) that have allowed their modern successors to recognize the falsity of the scriptores, and they may have followed them to the same conclusion. But all began from the same place, taking the six scriptores as the primary author-narrators behind the HA's numerous first-person statements. ${ }^{5}$ What they made of these aspects of the text must be viewed as an essential part of the $H A$ 's functioning.

This article is thus intended as a methodological call for more reader-focused work on the HA. Such work needs to properly consider the text's claims about its authorship and date, and to see them as parts of a unified fiction rather than as discrete bits of false data. This will, we may hope, allow for more methodologically varied approaches to the many existing interpretive cruxes, and open up new routes into territory already surveyed by so many distinguished scholars. Such work will also, and perhaps more importantly, make the $H A$ into a better witness to its own time. The kinds of puzzles a given culture or subculture generates, and the approaches it

3 Den Hengst 1981 is a foundational study of narrative voice in the HA, along with Den Hengst 1995. For more recent narrative-based approaches, see Pausch 2009; Zinsli 2014, 141-153; Burgersdijk 2016; Van Nuffelen 2017 and Zinsli 2017. Of these, Burgersdijk makes an explicit argument for a unified narrative voice with multiple personae, while Zinsli treats the author as a primary narrator (in Genette's sense) and the scriptores as internal narrators. Such models are appropriate for readers who have already "solved the puzzle," but my assumption is that most readers will initially approach the text without that knowledge and that many of them will remain in that state and interpret the text accordingly. Such readers, while not fully knowing in an ironic sense, would still not be misreading to the same degree as, for example, a contemporary of Swift's who read the originally pseudonymous Gulliver's Travels as the authentic mariner's narrative it claimed to be.

4 Thus Syme 1968, 176: "The [scriptor] labels have been assigned without much thought. It is a gain to disregard them." Zinsli 2017, however, makes important observations about the distinct kinds of authorial statements associated with the different scriptores.

5 This is not taking into account any readers who "knew the secret" through connections with the author. An intermediate category likely existed of readers who came to the book already aware of its mysterious or questionable provenance. One may imagine this as an integral part of the book's contemporary reception, as with pseudonymous literature in more recent periods. For a comparison of the $H A$ with a doubly pseudonymous French novelist, Romain Gary, see Ratti 2014. 
takes in solving them, are valuable indicators of its overall mentality. This is the more true when the raw material for those puzzles is the defining political institutions and personalities of that culture. Better understanding how a text like the $H A$ worked in its historical milieu can illuminate what people in that milieu thought of the relationship of literature to politics in constructing and deconstructing an authoritative past and indeed of the Roman monarchy itself as a continuing but ever-changing political institution. ${ }^{6}$

Thus my project is by turns negative and speculative. To imagine late antique readers of the $H A$, we have to unlearn much "knowledge" that we perhaps share with the author but not his original readers. ${ }^{7}$ This does not, however, mean replacing knowing modern readers with uncritical ancient ones who act as a tabula rasa to be defined by the $H A$ 's rhetorical techniques. The $H A$ circulated in a world that had its own ways of addressing the issues the scriptores generate of incomplete knowledge, suspicious information and problematic attributions (similar problems can be seen in the "marginal" texts examined by Pauline Duchêne in this volume). It has long been recognized that the $H A$ author's preoccupations resemble those of his grammarian and scholiast contemporaries. ${ }^{8}$ Recent work, notably by Irene Peirano, has done much to show how pseudepigraphic literature such as the $H A$ functioned in such a literary culture. ${ }^{9}$

One key insight of Peirano's work on "fake” Latin poetry has been that such material was generated in response to learned readers' demand for full, detailed narratives of the careers and works of canonical poets. Works such as those in the Appendix Vergiliana filled gaps suggested by the poets' biographical statements, supplied juvenilia to which existing poems gave back-references and generated new episodes in poets' patronage relationships. The Historia Augusta represents the same principle as applied both to the canon of Roman emperors and to the sequential tradition of Roman historiography and biography. ${ }^{10}$ The idea that Rome's ruler was part of a line of functionally analogous characters going back to Caesar and Augustus remained a crucial ideological claim for emperors and subjects alike, and it was a natural literary expectation that there should be a corresponding sequence of historians and bi-

\footnotetext{
6 Issues of historiographical form as commentary on Roman politics can also be seen in Liotsakis' and Baroud's contributions to this volume.

7 One possible approach is to consider how humanist readers of the HA (above all Casaubon and Salmasius) approached questions of structure and authorship. In what follows I refer to them on the understanding that their particular reading agenda is interestingly different from ours but not necessarily similar to that of average fifth-century readers.

8 Notably by Syme 1968, 183-186.

9 See Peirano 2012, also the contributions in Martínez 2011 and Cueva / Martínez 2016.

10 In this article, I have consciously avoided making sharp generic distinctions between history and biography. Such distinctions are certainly present in the $H A$, but they serve less as objective categories than as terms in a discourse that the author manipulates in ways too complex to be dealt with here. For fuller consideration and references, see Rohrbacher 2016, esp. chapters 2 and 4, also Van Nuffelen 2017.
} 
ographers to pick up where Tacitus and Suetonius had left off. ${ }^{11}$ Both of these imagined sequences encountered problems in reality, especially when it came to the troubled years of the mid-third-century. It is to the literary portion of these problems that the HA ostensibly offers a solution in the form of a previously undiscovered Suetonius continuatus (or Marius Maximus auctus), but it describes that solution in complicated and inconsistent ways. ${ }^{12}$ The inconsistencies in the $H A$ that have led modern scholars to the single-author solution served for ironically aware ancient readers as markers pointing toward not an answer but rather a deconstruction of their initial ideological assumptions about the relationship of the Roman monarchy to the literary tradition.

The present article cannot hope to fully develop such a thesis. Rather my intent is to sketch an initial model of a reader-based approach to the major structural questions of the HA. Much of my argument will consist of a somewhat artificial exercise in which I imagine a two-stage reading process, at both stages of which readers have several options for how to process the corpus. The first stage is that of initial contact, where readers encounter a codex (or, less likely, a set of bookrolls) of whose contents they have little or no knowledge beyond that it contains lives of emperors. These readers do not "plunge straight in" to a full sequential reading, but instead try, by leafing through the codex and using whatever paratextual devices it provides, to establish the basics of what the $H A$ covers and who produced it. The impression they thus develop determines what if any further engagement with the text they pursue. That engagement makes up the second stage, in which readers encounter the details of the various lives and use the scriptores' first-person statements to determine their characteristics as authors, especially their dates and the extent of their complete works. This model of mine is by no means intended as a definitive account of how the $H A$ was read, but rather as a thought experiment to suggest the kinds of questions one might ask about that reading process. It is includes a great many assumptions and qualifications that others may correct or refine, and in many cases I reconstruct detailed scenarios which others will imagine with different details. There are also a number of important possibilities I have not considered. Particularly, for reasons of simplicity I assume a basically solitary reading experience, whereas in reality many, even most, readers will have processed the authorship question in social settings. ${ }^{13}$ There is much that cannot be considered in one article, and my hope is very much to provoke discussion rather than conclude it.

11 I am influenced here by the arguments of Eigler 2003 that in late antiquity a blurring of lines takes place between the past as events and the canonical literature that records those events, albeit for Eigler this phenomenon is restricted to the pre-Augustan past.

12 For the $H A$ as a solution to a perceived gap in the historical knowledge of the time, see Kemezis 2018.

13 I have also not engaged with any of the various specific identifications that have been proposed for the HA author, including recently Nicomachus Flavianus Senior (Ratti 2007), Naucellius (Thomson 2012) or Tascius Victorianus (Savino 2017). Each of these men's social circle would have differently 


\section{Methodological considerations}

Before one can talk about how readers encountered a text, naturally one must define the text they encountered. The various complexities of the $H A$ make it all the more necessary that I acknowledge certain assumptions of mine that, while shared in $H A$ scholarship to varying degrees, still should not go unstated and untested. To spare the patience of readers who are uninterested in or all too familiar with the various controversies, I will be as brief as possible in giving my own rationales. Beyond the first key premise, which I have already discussed, is that the $H A$ is indeed the product of a single anonymous author writing around or after the year 400, there are further assumptions regarding the $H A$ 's readers, namely that: (a) the $H A$ was written such that it could be read and understood by the general literate-elite public of Rome and the Latin provinces, rather than any smaller segment of that elite; ${ }^{14}$ (b) the $H A$ that readers encountered included the same thirty chronologically ordered lives that are found in modern editions, and only those thirty, with no substantial further material now lost; and (c) it also included the attributions to the scriptores as we have them now, along with adequate paratextual devices to convey them to readers.

Assumption (a) refers to the "implied readership" of the text rather than the actual readers, or a specific audience that a historical author may have had in mind. It is entirely possible that the author envisioned a particular small set of readers, and that some aspects of the text (e.g. coded religious polemic) are cued to them. It considerably less likely, however, that the text in reality remained within that small compass. ${ }^{15}$ The important thing is that the meanings I propose for the text were available to a relatively wide range of reading publics (in ancient terms), even if it did also contain meanings that were available a small set of initiates and only to them. If there is a "secret meaning" to the $H A$, it is enclosed in a great deal of material that the uninitated could process, and how they processed it can lead us to inferences about the wider literary culture. The readers I have in mind would at a minimum be familiar

determined the initial reception of the $H A$ by people who knew or suspected the author's identity. However, this effect would with wider circulation have diminished and given way to processes such as those imagined in my reconstruction.

14 The issue of a "generic reading public" is naturally problematic, for various approaches in this volume see the essays of Liotsakis and Duchêne.

15 As to actual readership, Thomson 2012, 103-114 argues that the HA originated in the family of the Symmachi and saw little further circulation before the eighth century, and related arguments are made by Mastandrea 2011. For the early transmission, see also Callu 1985. I am influenced by the arguments of Sánchez Vendramini 2018, that the evidence for ancient book-distribution practices suggests that keeping a text within a restricted circle was impracticable other than by drastically restricting the number of copies. Some of the arguments about he makes about Ammianus do not apply to a pseudonymous author, but the basic idea holds good that texts circulated as social currency in ways independent of the rhetorically constructed intended audience of a particular work. The related argument, that the $H A$ represents covert anti-Christian propaganda, has a long history, see most recently Ratti / Nardelli 2014. 
with canonical Latin authors and with the Roman historical tradition as represented by the fourth-century breviarists. ${ }^{16}$ Other than that, however, they would have been far from uniform in their levels of education or religious-ideological position, and that diversity would have led them to different readings, but no one of those readings is "correct" in the sense of uncovering a true level of meaning that invalidates what is available to other readers.

Assumption (b) is more complicated and controversial. The $H A$ as we have it has the appearance of incompleteness in two main respects. First, it begins with a seemingly complete Hadrian but one might have expected a preface and perhaps lives of earlier emperors as well. ${ }^{17}$ Second and more clearly, a lacuna is evident between the Maximus et Balbinus, which is to all appearances complete, and the Valeriani Duo, which begins in the middle of a sentence. ${ }^{18}$ The question is whether the material that would have filled these "gaps" ever existed, or whether the apparent incompleteness is a deliberate effect of the author's. Opinions on both questions are much divided and, short of a manuscript discovery, conclusive proof is unlikely to emerge. My own position is based on a balance of probability. The idea of a missing preface and a spurious lacuna are entirely consistent with the games the $H A$ author plays elsewhere with the extent of the collection and the existence of spurious literary works. ${ }^{19}$ However, it is still worth being cautious about constructing any interpretation that depends too heavily on assumptions in this area. ${ }^{20}$

Assumption (c) is evidently critical: there is no point in analyzing readers' response to features of the text unless those features were in fact perceptible to them. The names of the scriptores and the attributions to them of the various lives are known to us almost entirely from the paratextual apparatus of our manuscripts, which consist of incipits and explicits of varying content plus (in the case of our prin-

16 For the intellectual background to the breviarists, see Sehlmeyer 2009, esp. 73-114. The extensive study of Rohrbacher 2016 makes clear that the HA deploys a dense network of learned allusions, many of which would have been accessible to all Latin readers at a given level of education rather than any particular group of initiates, though Rohrbacher also imagines more specific allusions relevant to particular reading circles.

17 On the completeness or otherwise of the opening, see Chastagnol 1994, xxxv; Meckler 1996. 18 For the "lacuna question" see Birley 1976, Ratti / Desbordes 2000, vii-xxxviii, Rohrbacher 2016, 9-10 and (arguing for its authenticity) Savino 2017, 69-76, and most recently Stover 2020.

19 Rees 2014 has now argued that Ammianus also employs a "false incompleteness" technique by explicitly indicating (through text and paratext) the existence of thirteen "lost" books going back to Nerva, which (in Rees' view) never in fact existed.

20 As regards the ordering question, our principal (P) family of manuscripts does have several anomalies in the ordering of lives between the Marc. and Alex. Thomson 2012, 90-93 has argued that the non-chronological order of $\mathrm{P}$ was in fact original. This is thoroughly refuted by Paschoud 2013, see also Savino 2017, 98-103. In particular, the independent $\Sigma$ family preserves an almost exact chronological ordering, a point on which Thomson is mistaken. We can be reasonably secure that the remaining deviations are the result of earlier accidents in transmission. Important discussions of the manuscripts include Hohl 1913; Callu et al. 1992, xciv-ciii and most recently Mayer 2016. 
cipal manuscript family) an index. ${ }^{21}$ That index as we have it must have been compiled at a later stage of transmission, and we cannot know whether the $H A$ in its original form included such a device. ${ }^{22}$ However, the scribes who compiled our surviving system of paratexts necessarily derived the names and attributions from somewhere, presumably a series of analogous devices going back to the original, and the relatively consistent way in which the scribes present them argues for those devices being relatively complete, and the attributions secure. ${ }^{23}$

The devices in question, colophons and perhaps running heads, and the ability to use them by leafing back and forth, are to a considerable degree features of the codex form as opposed to the roll. ${ }^{24}$ We can be reasonably sure that the $H A$ originally circulated as a codex, and its particular form of literary play was greatly facilitated by that physical medium..$^{25}$ Nonetheless, we can be quite certain that whatever paratextual devices existed were much less easy to use than those in a modern printed edition, requiring tedious leafing back and forth, with potential for error. Thus we cannot assume that, even if readers had the information required to fully deduce the scriptor-attributions, all of them always took the effort to do so. On the contrary, they would have needed reasons to bother, and some will have found more or different reasons than others. Thus in what follows, I will propose a continuum from those readers who fully engaged with the scriptores to those who entirely failed to notice

21 The only information given in the body of the text is (a) Aelius Spartianus' name at the start of a dedicatory letter to Diocletian (Ael. 1.1) and (b) Vopiscus' references to Capitolinus, Lampridius and Pollio (see fig. 2).

22 Notably, the index (printed in the introduction to Hohl 1971) reflects the disrupted ordering of P, as well as mistaken attributions and variant spellings seemingly derived from the incipits and explicits. See Ratti / Desbordes 2000, x.

23 The only significant inconsistency of attribution is that the P index (and to varying degrees the $\Sigma$ tradition) attributes the Val., Gal., and Trig. to Capitolinus, although in the text (Arln. 2.1) Vopiscus attributes them to Pollio. The error is an effect of the lacuna before the Val. See Ratti / Desbordes 2000, vii-xix. Shedd 2021 has recently argued that the scriptor names are not original, but were added in the ninth century by the scribe of our earliest complete manuscript P (Pal. lat. 899) to a collection that lacked paratextual authorial attribution. Shedd does well to point out the constituent elements on which our modern system of attributions rests, but his argument relies too heavily on arguments from absence in the slight evidence for the tradition independent of $\mathrm{P}$, and does not adequately explain how the P scribe came to invent some scriptor-names and to inconsistently apply those that are found in the text to particular lives. It remains more credible that the attributions are the work of the same person who invented the names (and so many other textual elements) in the first place, though the attributions may well have reached the $\mathrm{P}$ scribe in a form substantially different from the one he gave to them. Shedd should also be consulted for his arguments about the range of the $H A$ 's lives and about the various apparent lacunae, though it has not been possible in this article for me to take full account of them.

24 On paratextual devices in late antique codices and their visual presentation, see Bischoff 1990, $78-79$.

25 For the apparent dominance of the codex by the late fourth century, see Roberts / Skeat 1983 and now Harnett 2017. Thomson 2012, 99 notes that the $H A$ 's own vocabulary in discussing books seems to reflect codex usage. 
their existence, and many positions in between. With these preliminaries, then, we may proceed.

\section{First impressions}

Returning thus to our readers, we find them confronted with a codex of whose contents they have at best a hazy idea. They have likely found out about it through a social interaction with a friend or literary professional, and they may thus have learned something of its contents, but their first order of business will be to ascertain fully its authorship and characteristics, and complexities immediately present themselves. The codex, assuming that it has a title at all, is labelled generically as Vitae principum or Vitae Caesarum, though perhaps the range of emperors covered is specified. ${ }^{26}$ If an index is provided, the process I am about to describe will be much simplified, but if not, readers will quickly realize that the collection's opening does not constitute any sort of general preface giving an overview of the whole. Any further inquiry will require relatively labor-intensive leafing-through of the contents and tracking of incipits and explicits, probably in sequential order at this stage, though we must allow for skimming and skipping.

Let us assume that readers do begin tracking authors sequentially through the paratext without reading far at this stage: the "problem" of the scriptores presents itself immediately and will shape their impressions of the text as a whole. One crucial function of the scriptor fiction is simply that of generating mystery and interest among readers in a culture that placed great importance on the identity of a text's author. ${ }^{27}$ The apparent obscurity of the names will deter readers hoping for someone more famous, but the $H A$ is evidently aimed at readers who are just as curious about unknown authors as about emperors. The names themselves may strike readers as unusual or signifying. ${ }^{28}$ Simply by stating the scriptor-names, the $H A$ declares itself a puzzle to be solved as well as a trove of new information.

That puzzle includes not simply the identities of the scriptores but also the process by which their writings came into readers' hands. As soon as readers realize they are dealing with a multi-author collection, the questions arise of how, when and by whom the collection was assembled. For the earlier lives, the problem presents itself

26 Our existing manuscripts have a variety of titles, most of which specify a range from Hadrian to Numerianus, see Chastagnol 1994, xi-xii. On the title, see also Thomson 2007. The question of an original title is connected with that of the "missing" preface, since the two would naturally have been lost together.

27 Dessau 1889, 392 in fact assumes that that author's main purpose in creating the six scriptores was to give his work wider circulation on the theory that six new authors stimulate more interest than one.

28 A common approach in modern scholarship has been to read them either as coded literary or historical allusions, or as references to the content of the works. See e.g. Honoré 1987; Birley 2002. 
gradually and relatively simple answers suggest themselves. The first seven lives introduce the first four scriptores sequentially, as if the lives in question were all they had written. The first two (Hadr., Ael.) are by Spartianus, whose full name and Diocletianic date are both given in the opening lines of the Aelius. With the Antoninus, we switch to three lives by Capitolinus (Ant., Marc., Verus), then one by Gallicanus ( $A v$. Cass.) and another by Lampridius (Comm.). Readers will notice the accelerating multiplicity of new names. Evidently some editor is pulling all of these items together, seemingly to maintain a continuing sequence. Such patterns of continuation, either conscious or imposed by a later editor, would be relatively familiar from collections such as the Panegyrici Latini or Jerome's and Rufinus' adaptations and continuations of Eusebius. ${ }^{29}$

The surprise then comes when the Pertinax turns out not to be by Lampridius or a fifth continuator, but rather by Capitolinus once again. Then Spartianus also returns for the Julianus and a long sequence of further lives interrupted only by Capitolinus' Albinus and later Macrinus. Lampridius is not heard from again until the $\mathrm{Di}$ adumenus followed by the Heliogabalus and Alexander, whereupon Capitolinus has the next three in a row (Mxmn., Gord., Max.-Bal.). Even relatively casual readers will notice the disintegration of the expected pattern of continuators. The more attentive will start to wonder if the scriptores were rather larger-scale authors than initially suspected. They may naturally infer that Capitolinus wrote a Commodus to fill in the sequence of his Marcus, Verus and Pertinax, or that Spartianus' Julianus, Severus and Niger would be rounded out with an Albinus. But these works, if they ever existed, have been replaced with the efforts of other scriptores by the anonymous editor, whose role now comes to include not just compilation but selection from a perhaps very large mass of available material. A further surprise then comes after the lacuna, when at some point during or after the mutilated Valeriani it becomes clear that we are dealing with a new scriptor, Trebellius Pollio, who then produces three more lives (Gal., Trig., Claud.) and cedes to Flavius Vopiscus as to a continuator, with no further alternation. Order seems to have returned, and readers can plausibly guess that the editor responsible for the collection is either the last scriptor Vopiscus or some combination of him and Pollio.

Readers in search of a date for the scriptores will even at this stage have had a few clues. We have seen the Ael. opening with an address to Diocletian. Readers who in their search for incipits also stop to notice at least the opening and closing lines of the various lives will see that Spartianus opens the Geta with an address to Constantine Auguste. Similarly Capitolinus addresses Diocletian at the end of the Macrinus and Constantine at the start of the Maximini. ${ }^{30}$ This sets an approximate time and

29 On the Panegyrici, see Nixon / Rodgers 1994, 3-7, with discussion of paratextual devices. For Jerome and Eusebius, see Burgess 2002, 26-32; for Rufinus, Humphries 2008. Burgess 2005 also proposes multiple recensions for the $K G$ history, presumably by continuators.

30 Readers would have to read further into a given life to find Gallicanus' mention of Diocletian ( $A v$. Cass. 3.3) and Lampridius' several apostrophes to Constantine (Hel. 2.4, 34.1 and Alex. 65.1). 
gives a plausible chronological progression for both scriptores. There is less to go on for the two last scriptores (and putative editors). Pollio in the opening of the Claudius mentions a "Constantius Caesar" as apparently still alive, and later in the text it becomes clear this means Constantius Chlorus, but readers at this first casual stage may well take it as being the future Constantius II. ${ }^{31}$ At this point the identity of the authors is still more of a mystery than their chronology.

The question of just which rulers are (or originally were) included in the corpus similarly moves from a solvable puzzle to a more complex one as readers peruse the codex. The opening of the Hadrian points in a couple of directions. Its first words, Origo imperatoris Hadriani vetustior a Picentibus, posterior ab Hispaniensibus manat, and the discussion that follows all have a distinct Suetonian ring. This suggests a literary model, but also highlights the lack of a preface such as that with which Suetonius' Caesares originally began. ${ }^{32}$ And further, if Spartianus (or his editor) is an imitator of Suetonius, may he not also be a continuator? That, however, would lead one to expect a Nerva and a Trajan that were perhaps lost along with the preface. ${ }^{33}$ It also likely raises the question of the HA's relationship to Marius Maximus, even before that author's name is repeatedly mentioned in the text. Maximus, a Severan-era senator, is usually credited by moderns with a set of twelve Antonine and Severan lives continuing Suetonius, which are now lost but were in circulation in the 390s. ${ }^{34}$ Readers' expectations of the $H A$ will have been heavily influenced by Suetonius, Maximus and the breviaries, and thus by the prevalent notion of a canonical sequence of rulers going back to Caesar and Augustus. These expectations the $H A$ will alternately confirm and frustrate as readers go through its sequence.

On the one hand, all the rulers that should be there after Hadrian are there, except for the lacuna. The greater anomaly is that the collection includes characters one would not expect, because they were never canonical emperors. Some are heirs who never attained sole rule, others are unsuccessful aspirants whose defeat in civil wars led them to be labelled usurpers. Readers encounter this phenomenon

31 On this point see p. 238 below.

32 Suetonius' preface is mentioned by John Lydus, writing in the 500s (De mag. 2.6, see Garrett 2015, 133-134 for its possible contents). It contained a dedication to Septicius Clarus, and the fact that the HA mentions Suetonius and Clarus together in another context (Hadr. 11.3) may be a reference to that passage. For the HA's relationship with Suetonius, see most recently Fry 2010; Rohrbacher 2016, 49-58.

33 The starting point would also have been suggested by Ammianus, and it is notable that Victor (11.12), Eutropius (8.1.1) and the Epitome de Caesaribus (11.15) all make Nerva's accession the occasion for a formal period break, see Sehlmeyer 2009, 78-79. The omission in the $H A$ is noted by humanist editors e.g. Salmasius (ad Hadr. 1.1), suspecting a lost opening.

34 The fullest treatment of what is known about Maximus is Birley 1997. Virtually nothing about this character is without controversy, however. See in particular Paschoud 1999, who doubts either that the author Maximus is the same person as the Severan consul or that his works consisted of imperial biographies. The dispute ultimately goes to whether Maximus can be seen as the principal source of accurate information for the HA's primary lives, on which see most recently Rohrbacher 2013. 
quickly, since the second life in sequence is that of Hadrian's would-be successor Aelius Caesar. Many will be uncertain who Aelius was, and they may pause at this point to read the preface in which Spartianus explains (to Diocletian) his having included such a figure. At all events, they will realize that their expectations based on the Suetonius/Maximus model will have to be modified. On an aesthetic level, this exposes a key tension and a potential division in the readership, that between completeness and selectivity. Are more lives better? Would even more be even better? Some readers will be anxious for more data, but others will find it distracting and time-consuming. The text of the $H A$ will play with this question, at times reveling in curiositas, at other times shunning fastidia. But the whole form of the collection is calculated to raise the issue.

The aesthetic question also has a normative analogue: do these non-canonical figures deserve to be memorialized, and on what basis? These were questions Suetonius and Marius Maximus had answered quite conservatively, keeping their protagonists rather to a minimum. ${ }^{35}$ The $H A$ does the opposite, at least at the start, and readers may wonder what this signifies. They may interpret it differently depending on how they had recently answered analogous real-life questions of how to think and speak about Valentinian II, Magnus Maximus or Eugenius. The writing, circulation and reading of usurpers' lives could never be innocent of politics. ${ }^{36}$ The question becomes all the more vexed when, after all these subsidiary lives, readers are then confronted with combined lives in the form of the Maximini Duo, Gordiani Tres and Maximus et Balbinus. All of these lives are ascribed to Capitolinus and the practice is continued by Pollio and Vopiscus, the former of whom takes it to its extreme with the Triginta Tyranni. The introduction of this controversy is the first of many points at which the $H A$ equivocates on historical questions that may generate divisions within its readership (a related phenomenon can be seen with Arrian in Vasileios Liotsakis' contribution to this volume).

The editor's role in this process is less than clear. Is the "expanded canon" of heirs and usurpers ultimately of his shaping, if only through his not having omitted dubious candidates? For particularly alert readers, there is one final wrinkle. The $H A$ in its current form has exactly thirty lives. This figure is not a predetermined natural result, since far more than thirty individuals are involved, and the flexible selection criteria of the scriptores or editor could easily have produced a different figure. The figure of thirty is the same as the number of books in the then-current edition of Tacitus, and one less than the total for Ammianus. ${ }^{37}$ And readers who take into account

35 Birley 1997 credits Maximus with a canonical sequence of twelve from Nerva to Elagabalus including Macrinus but not Verus. Other structures and numbers have been suggested, but there is no reason to suppose that figures such as Aelius, Avidius Cassius, Pescennius Niger or Clodius Albinus received lives of their own.

36 For reflections of fourth-century civil wars in the $H A$, see Grey 2010.

37 Jerome Comm. in Zach. 3.14 mentions the thirty books of Tacitus, presumably obtained by placing the Histories after the Annales. 
the ostensibly missing opening and lacuna will find the "original” total to have been thirty-six, thus three times Suetonius' or Maximus' total. ${ }^{38}$ Such parlor games are not out of place in a world where the number of books in a work was a generic statement rather than an arbitrary total. ${ }^{39}$ Moreover, the $H A$ throws in a suggestive clue in the title of the Triginta Tyranni, an evident reference to the Athenian oligarchy that would have been familiar from Nepos or Cicero. Readers who venture into that fascinating volume will find much play around the arbitrariness of the canonical number. $^{40}$

At this stage, however, such suspicions will not be dominant in many readers' minds. The $H A$ has created for itself a relatively plausible prima facie impression of a collection written in the years around 300 and assembled by some combination of editors and continuators. These hitherto unknown characters follow in the tradition of Suetonius and Maximus, but with an unconventional interest in the losers and might-have-beens of history. Their apparent end point with Carus and sons makes sense if they began writing under Diocletian. Crucial prefatory information has been omitted, but much may still be deduced from the content. Readers have both a basic set of expectations to satisfy their conventional side and more than a whiff of the eccentric to whet their curiosity. Will the text as they find it satisfy or disappoint?

\section{Further engagement}

While the impression I have just sketched will be shared by a relatively wide segment of the HA's readership, their next steps will be dictated by a diverse set of further reactions. Different readers will approach the text at different points with different questions, leading to many reading patterns beyond the strictly sequential. These will be greatly influenced by how readers use their basic knowledge of the new collection's contents to position it relative to their existing reading and interests.

Thus for some, the HA will be a continuation of Suetonius, and the natural starting point will indeed be the Hadrian, with due regrets for the missing Nerva and Trajan and perhaps little interest in the Aelius and its ilk. Those who are already acquainted and satisfied with Marius Maximus will by contrast be drawn either to the later lives that are beyond his range or to the minor lives that supplement his coverage of the earlier reigns. Their first proper introduction to the $H A$ may be Spartianus' preface to the Aelius, or Lampridius' in medias res opening to the Alexander.

38 This assumes the lacuna contained four additional lives (see Fig. 1), those being (i) Philip and son; (ii) Decius and son; (iii) Gallus, with Volusianus and Hostilianus and (iv) Aemilianus. This version of the canon can be found in the breviaries, see Victor 28-31; Eutropius 9.3-6, Epit. 28-31. 39 Barnes 1998, 23-31 supplies examples.

40 For discussion see Kemezis 2018, 310-313. Callu et al. 1992, xlviii-lx also attaches much significance to the number, though with very different conclusions. 
Those who set the work beside Ammianus or the breviary tradition may well take a fully sequential approach, but still others will select entry points based on personal preoccupations, the wish to track down a putative ancestor or a favorite anecdote. And those who see the imperial past through the prism of religious conflict will be disappointed to find no coverage of Philip the quasi-Christian, Decius the persecutor or the Tetrarchy. We should finally anticipate that some readers are focused more on author than subject and will choose first to read all the works of (say) Spartianus, then Capitolinus and so forth, even though this would seem to run counter to the editor's chronological scheme. ${ }^{41}$

These various entry points will create radically different experiences because of the HA's uneven content. This is how ancient readers will likely perceive what for moderns is the distinction between the relatively factual, Suetonian "primary lives" (meaning largely those of sole-reigning emperors from Hadrian to Elagabalus), and the more fictional "secondary lives" (usurpers and heirs from the same period) and later lives (Alex. and after). ${ }^{42}$ The most common modern interpretation of these distinctions is a developmental story in which the "primary" lives are written first and represent a norm from which the sole author progressively deviates into fiction or fraudulence as his sources and predilections change. ${ }^{43}$ Moderns have taken the "primary" lives as normative in no small part because they are the most useful to us as historians and conform most closely to our classicizing expectations. This second reason will be shared by the part of the ancient readership that expects a Suetonian continuator. Others may in fact find the (pseudo-) documentary or epistolary approach of the minor and later lives more to their taste, even if they are eventually disappointed by the content of some of these letters and documents. ${ }^{44}$ And finally, some segment, those who are familiar with Maximus or the Greek tradition but still choose to read the corresponding $H A$ lives, will eventually realize how much of the HA's earlier content is drawn wholesale from those authors, and how misleading are the scriptores' acknowledgements of that relationship. ${ }^{45}$ This may provoke in them suspicions about the legitimacy of the collection as a whole.

Readers may be perplexed, however, because these stylistic variations in the collection's content map imperfectly on to the different scriptores. Those who range

41 One such reader would seem to have been the compiler of the florilegium found in Vat. Lat. 5114, for which see Hohl 1913, 411-414.

42 Various versions of these classifications go back to at least Mommsen 1890 and were systematized in particular by Barnes 1978.

43 Notable versions of this developmental approach can be seen in Syme 1968; Honoré 1987; Callu et al. 1992, xiv-lxx; Den Hengst 1995, 165-167 Savino 2017, 59-103.

44 Cameron 2011, 778-782 points out the HA's links with such Greek works of pseudo-historiography as Ptolemy the Quail's New History or Ps.-Plutarch's Parallela Minora. One might add the works of Trojan revisionism (Dictys Cretensis and Dares the Phrygian) then emerging in Latin translations. Duchêne's contribution in this volume considers the relationship of parodic works to the genre of historiography.

45 On the relationship of Maximus and the $H A$, see note 34 above. 
widely will notice that Capitolinus' Clodius Albinus is nothing like his Marcus, but curiously similar to Spartianus' Aelius or even Vopiscus' later works. Furthermore, the scriptores' statements about themselves will cause difficulties once readers try to assemble a coherent picture of who these authors were. Crucial questions include, first, the scriptores' dates and relationship to the events they narrate and, second, the extent and intent of their literary oeuvre, as mediated through the work of the anonymous editor. Many of these questions will play out differently for the first four scriptores (Spartianus, Capitolinus, Lampridius, Gallicanus) as opposed to the last two (Pollio, Vopiscus), but most readers will probably have at least some interest in all six, given their novelty and the vague interconnectedness of their work. Readers' approaches may owe less to the norms of historiography or biography than to ways in which they unravelled the stories told discontinuously in elegiac poetic cycles or epistolary collections (for the latter, see Ari Zatlin's contribution in this volume).

The dating question will revolve around the clearest cues, the many explicit mentions of living emperors. ${ }^{46}$ The first stage of reading will have left all but the most cursory readers with some sense that the scriptores are located in the Tetrarchic or Constantinian period. This will disappoint those in search of contemporary testimony for Antonine or Severan events, but stimulate others' curiosity about the years of the mid-to-late-third century whose literature and history are probably less familiar than those of periods farther in the past. The latter readers in particular will naturally proceed to pin the scriptores down to some more precise time (or place) within that period of tumult, and to establish a relative chronology among the six: a disproportionate number of these readers may follow an author-based rather than chronological order.

As noted above, a cursory initial survey has probably given them a rough sense of the scriptores' dates. Further reading of the first four scriptores adds substance to this pattern, giving the impression that the four were more or less contemporaries who wrote the Antonine and early Severan lives under Diocletian and later ones under Constantine. ${ }^{47}$ Spartianus addresses Diocletian three times (Ael. 1.1; Sev. 20.4; Nig. 9.1) and Constantine once in a subsequent life (Geta 1.1). Gallicanus' sole effort has an apostrophe to Diocletian (Av. Cass. 3.3). For Lampridius, on the other hand, all the addresses are to Constantine, but they all come in two relatively "late" lives (Hel. 2.4, 34.1; Alex. 65.1), so it is not clear if he is later than or contemporary with the scriptores who address both emperors. ${ }^{48}$ Capitolinus is a slightly

46 Ancient readers would likely not, however, notice many of the smaller but conclusive details that led Dessau and others to discount the Tetrarchic-Constantinian date, e.g. the anachronism of attributing to Constantius Chlorus the dynastic fiction about Claudius Gothicus.

47 The scriptores' references to their own work uniformly support the assumption that lives are composed in chronological order, whether or not in reality this was the author's practice.

48 At Hel. 35.6 Lampridius refers to a series of Constantinian victories that was not complete until quite late in his reign, but to realize this requires an immediate command of absolute dating that 
more complicated case. His six addresses to emperors are the most of any scriptor: the first two to Diocletian (Marc. 19.12; Verus 11.4) and the last two to Constantine (Mxmn. 1.1; Gord. 34.6) follow the established pattern. The middle two are out of sequence, however, since Constantine is addressed in the Albinus (ch. 4.2), only to have an unexpected return to Diocletian at the end of the Macrinus (ch. 15.4). The discrepancy will likely not go entirely unnoticed, especially given that the Albinus passage refers to senatorial families that were still prominent in the Theodosian period, but neither is it glaring enough to constitute a major crux.

The content of these various addresses gives only limited insight into the scriptores' own position. The addresses to the emperors are mostly generic and do not guarantee social or even physical closeness. ${ }^{49}$ The deferential tone and quasi-dedicatory language will likely evoke courtier-historians such as Victor, Eutropius or Festus and signal distance from the classicizing tradition of an Ammianus or Tacitus. ${ }^{50}$ Readers for whom Constantine's memory inevitably suggests religious change will again notice the utter absence of this topic in the apostrophes, but the abundant discussion of the imperial office itself and the appropriate qualifications and virtues of a ruler will resonate with those who know Constantine from the Panegyrici Latini as then circulating in Italy. ${ }^{51}$

The last two scriptores are once again clearly different. Neither one directly addresses an emperor, making their apostrophes instead to peers among the literate elite. ${ }^{52}$ Vopiscus has overall the fullest personality of any scriptor, which, without giving any real evidence, furthers the impression that he is the final continuator and editor of the collection. That impression is strengthened by the prefatory passages in which Vopiscus explicitly refers first to Pollio (Arln. 2.1) and then to Lampridius and Capitolinus (Prob. 2.7), all seemingly as figures of the past. If readers already suppose from their initial perusal that Pollio has continued the works of the first four scriptores and Vopiscus has continued Pollio's, they can easily see Vopiscus' statements as confirmation. But readers who go beyond prefatory statements will encounter major difficulties of absolute dating. Both Pollio and Vopiscus refer in the third person to a "Constantius". Readers who only glanced at the Claud. preface might be unsure which Constantius was in question, but as they read deeper, it becomes clear that both scriptores mean Constantius Chlorus, and that as of the narra-

few ancient readers would have displayed. I cannot find any discussion of the point in humanist editions.

49 Marc. 19.12 (Capitolinus to Diocletian) and Hel. 34.4-6 (Lampridius to Constantine) mention remarks of the respective emperors that might be part of a private conversation, but they might equally be read as a pronouncement of the emperor's to some larger audience. For extended analysis of the Constantine-apostrophe, see Zinsli 2014, 815-876.

50 For the marked contrast with Ammianus and Tacitus, see Rohrbacher 2016, 62.

51 On the HA's knowledge of the panegyrics, see Chastagnol 1994, xc-xci. Zinsli 2014, 254-264 argues that the Hel. in particular has strong intertextual links with Eusebius' Life of Constantine, which include Lampridius' self-presentation.

52 On these addressees, see Burgersdijk 2016. 
tive present he and other Tetrarchic rulers are still alive and Constantine is not yet a figure of note. ${ }^{53}$ This would place Pollio and Vopiscus squarely in the middle of the range of the first four scriptores, indeed twenty years earlier than Lampridius' statements in the Hel. Ingenious readers who really want to salvage the continuation model may devise at least a partial solution to the dilemma, but most, once they notice the problem at all, will find it baffling.

Those readers who have already encountered the various prefatory statements of the first four scriptores will realize that this bafflement has a larger context. The more readers engage with the scriptores' own statements, the more they will sense an iceberg of which the present collection is but the tip. For all the scriptores but Vopiscus, works are mentioned or implied beyond those that are extant. The most obvious instances are those of Spartianus (Ael. 7.5) and Gallicanus (Av. Cass. 3.3), each of whom claims to be planning a complete collection running from Augustus to the narrative present and including minor characters as well as sole rulers. ${ }^{54}$ Spartianus in the Niger (9.2) anticipates writing a life of Clodius Albinus, but that emperor is in fact covered by Capitolinus, who claims (Alb. 1.4) to have already written a life of Niger. Lampridius (Diad. 6.1) likewise claims a Macrinus, thus also overlapping with Capitolinus. Furthermore, in the Heliogabalus he expresses (to Constantine) an intention of continuing on to Alexander, which he does, but also to the Gordiani (actually by Capitolinus), Claudius (by Pollio), Aurelian (by Vopiscus) and eventually to various Tetrarchic figures and Constantine himself, none of whom will actually fall within the collection at all.

On this question, the last two scriptores are a bit less problematic. Pollio does at one point (Trig. 31.8) imply that he intends to write lives up to and including Diocletian. In the Aurelian, however, Vopiscus helpfully informs us that Pollio wrote $a d u$ obus Philippis usque ad divum Claudium et eius fratrem Quintillum imperatores, leading us to suppose that Pollio's sequence has been terminated by his inactivity or death. This works nicely for the continuation hypothesis and allows Pollio to neatly fill the lacuna before the Val. Regarding his own writings, Vopiscus repeatedly tells us that the Aurelian is indeed his first effort. He further observes that no other Latin author has covered that ruler, which will raise suspicions that the earlier scriptores left their grand projects incomplete..$^{55}$ The question of a stopping point comes up against the problem of writing about living rulers. Lampridius has already broached (or, depending on the reader's viewpoint, will later broach) this topic, and anticipated continuing right up to his addressee Constantine (Hel. 34-35). Where he seems eager to rush in, Vopiscus fears to tread. In the Quadr., he looks forward to writing of Carus and his sons, but adds that Diocletian and his colleagues "must be described in a grander manner" (Quadr. 15.10: stilo maiore dicendi sunt).

53 See in particular Claud. 13.2 and Arln. 44.4.

54 See also Mxmn. 1.3, where Capitolinus anticipates further lives of magni imperatores seemingly beyond his remaining two lives (Gord. and Max.-Bal.).

55 This is the assumption e.g. of Casaubon 1603. 
Very similar language is used in the last chapters of Eutropius (10.18.3) and Ammianus (31.16.9) to beg off a task better suited to panegyrists. ${ }^{56}$

Working within the modern single-author hypothesis, this represents a relatively consistent picture. Nearly all these methodological statements can be read as referring to a single project that originally had a unified narrative voice. The fiction of the scriptores has, in this reading, been added on late and carelessly, hence the mistaken cross-references. Such a picture is not (at least initially) available to ancient readers, although some will be less thoroughly engaged with the authorship issue, and will tend to assume casually that Spartianus' and Gallicanus' very similar statements about usurpers' lives are by the same rather repetitious author, or that the Niger author did write the Albinus as well. Those who are more attentive may conclude that the editor has made mistakes in the ascriptions, without thereby being led to question the fiction as a whole. ${ }^{57}$ They may, however, begin to see the inconsistencies not as individual anomalies to be smoothed out, but as cues toward some larger overall irony. ${ }^{58}$ Conversely it may strike them, as it struck Casaubon, that while the specific statements of the scriptores are inconsistent, their general characteristics, both biographical and stylistical, are improbably similar. ${ }^{59}$ And once one starts looking for ironic signposts in the $H A$, any number of discrete passages present themselves. To give one example, Lampridius, after announcing in the Heliogabalus his plan to continue on through Constantine, later in the Alexander (64.2) hedges, and says he will continue si vita subpeditaverit. The phrase is not an unusual one, but the most apposite use of it in earlier Latin is undoubtedly when Tacitus, in the Histories preface, promises to write of Nerva and Trajan si vita suppeditet. ${ }^{60}$ He notably failed

56 On the Ammianus passage and its various intertextual links, see Kelly 2007.

57 Readers may find the "mistaken editor" hypothesis the more attractive in that reassigning the $\mathrm{Al}$ binus to Spartianus and the Macrinus to Lampridius would create unbroken sequences of six lives by Spartianus and then four by Lampridius. Humanist editors, working with variant manuscript traditions, generated many disputes over attribution, while Mommsen 1890, 242-252 was willing to rearrange several attributions in order to rescue his argument for separate "Diocletianic" and "Constantinian" sequences of lives, and Savino 2017, 76 - 78 has recently suggested a similar though less drastic move.

58 Van Nuffelen 2017 considers the authorial inconsistencies as part of an ironic strategy leading readers to the truth of single authorship, though for him the most important ironies have to do with the cultural prestige of biography as a genre. Similarly, Zinsli 2017 views the anachronisms as "entry-points" (Einstiegstellen) that make it inappropriate to speak of the HA as a "forgery."

59 Casaubon ad Hadr. 1.1, comes perhaps the closest of Dessau's predecessors to anticipating his solution, though with little sign of ironic awareness: Satis enim mirum videtur nobis, quod de Aelio Spartiano, Aelio Lampridio \& Julio Capitolino vulgati libri suggerunt: omnes hos tres cum sub Diocletiano coepissent florere, ad Constantini tempora durasse: omnes Imperatorum omnium vitas tempore eodem scribere aggressos (\& quidem stylo ita parum dissimili, ut discrimen vix ullum liceat notare), pariter in opere instituto progressos, pariter defuisse. Ita plane est necesse, si vulgarium codicum non fallunt nos inscriptiones.

60 Hist. 1.1. Although the HA refers to the historian Tacitus twice (Arln. 2.1; Tac. 10.3), scholars have generally doubted that this reflects any deep engagement with his text. For a more optimistic reading, 
to do so, as the HA's readers will likely know. The $H A$ editor perhaps set out to remedy that omission, but if so his work is now incomplete through the loss of precisely the same two emperors. At what point do the neatly filled gap and its equally neat reopening become too neat? Readers may be nudged along the way when they encounter Vopiscus three times using the same words (with morphological variants) to describe his own future productions. ${ }^{61}$

However they pick up irony, though, all attentive readers will come to reflect on the work of the anonymous editor who may or may not be Vopiscus. Based on the scriptores' statements about themselves, this character seemingly had access to a very large mass of previously unsuspected literature, the more so if one considers that the scriptores in turn mention dozens of phoney authors. ${ }^{62}$ His principles for selecting the $H A$ lives seem at once simple (one life for each emperor) and opaque (separate vs. combined lives, why one scriptor over another?). He has greatly expanded the range of what can be known about emperors, but for some readers he has only created an appetite for more, not unlike that felt by humanists and later philologists. ${ }^{63}$ How can we be satisfied with but one small sample of the vast literary output of Vulcacius Gallicanus? Others may find Gallicanus' Avidius Cassius to be of a mediocrity appropriate to its subject, and be glad that the editor has spared us all the wasted time of reading his further efforts. ${ }^{64}$ Either way, however, the question of what constitutes a proper author worthy of readers' attention has been brought much to the foreground and been closely linked with that of what constitutes a proper emperor worthy of an author's attention.

\section{Conclusion}

The June 1939 issue of the American literary journal Poetry included a rather strange poem titled "Draft Ode for a Phi Beta Kappa Occasion," written by a poet named Rolfe Humphries, whose name regular readers of the journal would have recognized. ${ }^{65}$ According to a prefatory note, the poem is "written in the tradition that there must be an average of one classical allusion to the line, and that the metre must be unrhymed iambic pentameter." From its first line ("Niobe's daughters

see Velaza 1997, with reference to this passage at $250-52$. On the availability of Tacitus in the HA's milieu, see Zecchini 1991.

61 Arln. 24.9; Prob. 1.5, 24.8.

62 On these characters, see Syme 1976; Chastagnol 1994, cvii-cxii.

63 Casaubon 1603 for one displays much animus toward the anonymous editor: Atque ego non dubito istum Tribonianum cum hoc [sc. the work of selection] fecisset, visum sibi bellum hominem, qui erat saperda merus.

64 I am grateful to Dennis Pausch for suggesting this view of the editor as anthologist giving readers access to only the best.

65 He is mainly remembered today for his translations of Lucretius, Virgil and Ovid. 
yearn to the womb again") it amply fills that promise. Its twenty-eight lines contain at least that number of ancient names, but little other discernable meaning. The speaker in the last line apostrophizes the "Sons of Columbia" and seems to be trying to say something like "there are some very bad things going on in the world, and you need to rise to the challenge." Given the date, one can guess what troubles he has in mind, but what implications he draws about them are unclear to say the least and the poem as a whole is awful. That is until one reads it as an acrostic whose initial letters spell "NICHOLAS MURRAY BUTLER IS A HORSE'S ASS," referring to the then president of Columbia University, a Nobel Peace prize-winner and national icon of academic elitism.

The story became a minor scandal at the time, known and repeated by far more people than ever read the poem itself. Why, after all, should they have bothered, once its secret was public? Nonetheless, to a reader eighty years later, the poem itself is a not unappealing subject for cultural-historical reflection. One wonders naturally about Humphries' motives, but also about who figured the solution out and how, and what they thought the author was up to. The specific content has much to tell us on both fronts. The poem has many clues that it is a parody of some kind. The title and note are very odd (Why is a "draft" being published? What is this "tradition"?) and the style is not merely deficient in itself but quite unlike the poet's other work of the time. Many people (including perhaps the journal editors) perhaps detected elements of parody without noticing the acrostic, while it cued others to look closer for just such a trick. ${ }^{66}$ Furthermore, inarticulate as the poetic speaker is, his words still position him within several cultural controversies of the time, about the aesthetics of modernist literature, about education and social class in New Deal America, and above all about the developing crisis in Europe. These were all questions on which Nicholas Murray Butler had public stances, often at odds with those of Humphries. ${ }^{67}$ Between the multiplicity of issues at stake and readers' varying levels of ironic awareness, the range of possible readings of this short text is remarkable. Humphries cannot have intended or anticipated all of them, but their availability is still a telling reflection of the shape of cultural politics at the time.

66 Humphries himself, in a now-published letter (Gillman / Novak 1992, 163-164), draws a friend's attention to the poem, noting only that "There is a key to it, which I will expound if you have not, by the time I see you, discovered it.” The August 1939 issue of the journal (294) contains an editorial note disavowing any knowledge of the prank, which apparently was only pointed out to the editors several weeks after publication.

67 Butler, then seventy-seven years old and president of the American Academy of Arts and Letters, was known for a reactionary taste in literature. Politically, he was a fierce anti-communist who had favored Chamberlain's diplomatic approach only to become a vocal advocate of U.S. entry into the war after September 1939. Humphries was more than thirty years younger and a left-wing activist known for his advocacy of the Republican side in Spain. See respectively Rosenthal 2006 and Limmer 1992. 
Cultural historians of the 1930s, however, can choose from thousands of documents and artifacts on which similar exercises could be carried out. For them the Humphries prank can safely remain an amusing anecdote. Romanists have no such abundance, and must be grateful for what we get. The Historia Augusta's enigmatic form can be an annoyance that we need to clear away before we can learn from it what we want. But from another perspective that form can itself be among the text's most revealing features. To reconstruct its meaning requires much speculation and often fails to yield satisfyingly definite answers. We cannot know what any actual author or reader thought of the $H A$, but we can map out what the text allowed them to think, the options it presented and framed for them, the discursive strands that it connected to and extended. In doing so, we can gain a little new perspective on a political and literary landscape of which our view is forever blurry and partial. The $H A$ is remarkable for what it actually is, but perhaps even more for what in its own context it could be. To appreciate such a work, we need both multiple reading perspectives of our own and a consciousness of those perspectives in the ancient world.

\section{Bibliography}

Baldwin, B. (2010), "'Contemporary' Allusions in the Historia Augusta", in: C. Deroux (ed.), Studies in Latin Literature and Roman History 15, Brussels, 446-462.

Barnes, T.D. (1978), The Sources of the Historia Augusta, Brussels.

Barnes, T.D. (1998), Ammianus Marcellinus and the Representation of Historical Reality, Ithaca, N.Y.

Birley, A.R. (1976), “The Lacuna in the Historia Augusta”, in: J. Straub (ed.), Bonner Historia-Augusta-Colloquium 1972-1974, Bonn, 55-62.

Birley, A.R. (1997), “Marius Maximus: The Consular Biographer”, in: Aufstieg und Niedergang der römischen Welt 2.34.3, 2678-2757.

Birley, A.R. (2002), “'Trebellius Pollio' and 'Flavius Vopiscus Syracusius”, in: G. Bonamente and F. Paschoud (eds.), Historiae Augustae Colloquium Perusinum VIII, Bari, 33-47.

Bischoff, B. (1990), Latin Palaeography: Antiquity and the Middle Ages, D. Ó Cróinín and D. Ganz, trans., Cambridge.

Burgersdijk, D.W.P. (2016), “Qui vitas aliorum scribere orditur: Narratological Implications of Fictional Authors in the Historia Augusta", in: K. De Temmerman and K. Demoen (eds.), Writing Biography in Greece and Rome: Narrative Technique and Focalization, Cambridge, $240-256$.

Burgess, R.W. (2002), “Jerome Explained: An Introduction to His Chronicle and a Guide to its Use”, in: Ancient History Bulletin 16/1, 1-32.

Burgess, R.W. (2005), “A Common Source for Jerome, Eutropius, Festus, Ammianus and the Epitome de Caesaribus between 358 and 378, along with Further Thoughts on the Nature of the Kaisergeschichte", in: Classical Philology 100/2, 166-192.

Callu, J.-P. (1985), “La première diffusion de l'Histoire Auguste (vie-ixe s.)”, in: J. Straub (ed.), Bonner Historia-Augusta-Colloquium 1982/1983, Bonn, 89-129.

Callu, J.-P. et al. (eds.) (1992), Histoire Auguste: Tome I.1. Vies d'Hadrien, Aelius, Antonin. Collection des universités de France, Paris.

Cameron, A. (2011), The Last Pagans of Rome, Oxford. 
Casaubon, I. (1603), De sex istis scriptoribus historiae Augustae \& de hac editione prolegomena, Paris.

Chastagnol, A. (1994), Histoire Auguste: Les empereurs romains des Ile et Ille s., Paris.

Cueva, E.P. and J. Martínez (eds.) (2016), Splendide mendax: Rethinking Fakes \& Forgeries in Classical, Late Antique \& Early Christian Literature, Groningen.

Den Hengst, D. (1981), The Prefaces of the Historia Augusta, Amsterdam.

Den Hengst, D. (1995), "Selbstkommentar in der Historia Augusta", in: G. Bonamente and G. Paci (eds.), Historiae Augustae Colloquium Maceratense III, Bari, 151-167.

Den Hengst, D. (2002), “The Discussion of Authorship”, in: G. Bonamente and F. Paschoud (eds.), Historiae Augustae Colloquium Perusinum VIII, Bari, 187-195.

Dessau, H. (1889), “Über Zeit und Persönlichkeit der Scriptores Historiae Augustae”, in: Hermes 24/3, 337-392.

Eigler, U. (2003), Lectiones vetustatis: Römische Literatur und Geschichte in der lateinischen Literatur der Spätantike, Munich.

Fry, C. (2010), "Suetonianus quidam: l'auteur de l'Histoire Auguste en utilisateur du style suétonien", in: L.G. Milić and N. Hecquet-Noti (eds.), Historiae Augustae Colloquium Genevense in honorem F. Paschoud septuagenarii, Bari, 135-151.

Garrett, P. (2015), “Reconstructing the Lost Beginning of Suetonius' Divus Iulius", in: Antichthon 49, $110-134$.

Gillman, R. and M.P. Novak (eds.) (1992), Poets, Politics and Poetics: America's Literary Community Viewed from the Letters of Rolfe Humphries, Lawrence, Kan.

Grey, C. (2010), "Civil War? What Civil War? Usurpers in the Historia Augusta", in: B. Breed et al. (eds.), Citizens of Discord: Rome and its Civil Wars, Oxford, 86-101.

Gurney, P.J. and L.W. Gurney (1998), "Authorship Attribution of the Scriptores Historiae Augustae", in: Literary and Linguistic Computing 13/3, 119-131.

Hackius, P. et al. (eds.) (1671), Historiae Augustae scriptores VI. Aelius Spartianus, Julius Capitolinus, Aelius Lampridius, Vulc. Gallicanus, Trebell. Pollio, Flavius Vopiscus. Cum integris notis Isaaci Casauboni, Cl. Salmasii \& Jani Gruteri, Leiden.

Harnett, B. (2017), "The Diffusion of the Codex", in: Classical Antiquity 36/1, 183-235.

Hohl, E. (1913), "Beiträge zur Textgeschichte der Historia Augusta", in: Klio 13, 258.

Hohl, E. (ed.) (1971), Scriptores Historiae Augustae. Editio stereotypa correctior, Leipzig.

Honoré, T. (1987), "Scriptor Historiae Augustae", in: Journal of Roman Studies 77, 156-176.

Humphries, M. (2008), “Rufinus's Eusebius: Translation, Continuation, and Edition in the Latin Ecclesiastical History", in: Journal of Early Christian Studies 16/2, 143-164.

Kelly, G. (2007), “The Sphragis and Closure of the Res gestae”, in: J. Den Boeft et al. (eds.), Ammianus after Julian, Leiden, 219-241.

Kemezis, A.M. (2018), "The Fictions of Tradition in the Later Lives of the Historia Augusta", in: 0. Devillers and B.B. Sebastiani (eds.), Sources et modèles des historiens anciens, Bordeaux, 307-318.

Limmer, R. (1992), “In the American Grain: A Biographical Essay”, in: R. Gillman and M.P. Novak (eds.), Poets, Politics and Poetics: America's Literary Community Viewed from the Letters of Rolfe Humphries, Lawrence, Kan., 9-34.

Lippold, A. (1998), “Die Historia Augusta: Eine Sammlung römischer Kaiserbiographien aus der Zeit Konstantins", in: A. Lippold and G.H. Waldherr (eds.), Die Historia Augusta, Stuttgart, 1-14.

Martínez, J. (ed.) (2011), Fakes and Forgers of Classical Literature - Falsificaciones y falsarios de la Literatura Clásica, Madrid.

Mastandrea, P. (2011), “Vita dei principi e Storia romana, tra Simmaco e Giordane”, in: L. Cristante and S. Ravalico (eds.), Il calamo della memoria IV, Trieste, 207-245. 
Mayer, M. (2016), "Génesis y evolución del texto de la Historia Augusta: Consideraciones a propósito de la Vita Pescenni Nigri", in: J. Velaza (ed.), From the Protohistory to the History of the Text, Frankfurt am Main, 313-332.

Meckler, M. (1996), “The Beginning of the Historia Augusta”, in: Historia 45/3, 374-375.

Mommsen, T. (1890), “Die Scriptores Historiae Augustae”, in: Hermes 25/2, 228- 292.

Nixon, C.E.V. and B.S. Rodgers (eds.) (1994), In Praise of Later Roman Emperors: The Panegyrici Latini, Berkeley, Calif.

Paschoud, F. (1999), "Propos sceptiques et iconoclastes sur Marius Maximus”, in: F. Paschoud (ed.) Historiae Augustae Colloquium Genevense, Bari, 241-254.

Paschoud, F. (2013), Review of M. Thomson. Studies in the Historia Augusta, 2012, in: Histos 7, $362-373$.

Pausch, D. (2009), "Libellus non tam diserte quam fideliter scriptus? Unreliable Narration in the Historia Augusta", in: Ancient Narrative 8, 115-136.

Peirano, I. (2012), The Rhetoric of the Roman Fake: Latin Pseudepigrapha in Context, Cambridge.

Ratti, S. (2007), "Nicomaque Flavien Senior auteur de l'Histoire auguste", in: G. Bonamente and H. Brandt (eds.), Historia Augusta Colloquium Bambergense, Bari, 305-317.

Ratti, S. (2014), “Les ancêtres d’Émile Ajar”, in: Médium 40/3, 109-124.

Ratti, S. and O. Desbordes (eds.) (2000), Histoire Auguste: Tome IV.2. Vies des deux Valériens et des deux Galliens. Collection des universités de France, Paris.

Ratti, S. and J.-F. Nardelli (2014), "'Historia Augusta contra Christianos': Recherches sur l'ambiance antichrétienne dans l'Histoire Auguste", in: Antiquité tardive 22, 143-155.

Rees, R. (2014), “Intertitles as Deliberate Misinformation in Ammianus Marcellinus", in: L. Jansen (ed.) The Roman Paratext: Frame, Texts, Readers, Cambridge, 129-142.

Roberts, C.H. and T.C. Skeat (1983), The Birth of the Codex, Oxford.

Rohrbacher, D. (2013), “The Sources of the Historia Augusta Re-Examined”, in: Histos 7, 146-180.

Rohrbacher, D. (2016), The Play of Allusion in the Historia Augusta, Madison, Wis.

Rosenthal, M. (2006), Nicholas Miraculous: The Amazing Career of the Redoutable Dr. Nicholas Murray Butler, New York.

Sánchez Vendramini, D.N. (2018), "The Audience of Ammianus Marcellinus and the Circulation of Books in the Late Roman world", in: Journal of Ancient History 6/2, 234-259.

Savino, E. (2017), Ricerche sull' Historia Augusta, Naples.

Sehlmeyer, M. (2009), Geschichtsbilder für Pagane und Christen: Res romanae in den spätantiken Breviarien, Berlin.

Shedd, M.P. (2021), “The Historia Augusta Before Ms Pal. Lat. 899: Lost Manuscripts and Scribal Mediation”, in: Classical Quarterly 71/1, 402-421.

Stover, J.A. (2020), “New Light on the Historia Augusta", in: Journal of Roman Studies 110, 167-198.

Stover, J.A. and M. Kestemont (2016), "The Authorship of the Historia Augusta: Two New Computational Studies", in: Bulletin of the Institute of Classical Studies 59/2, 140-157.

Syme, R. (1968), Ammianus and the Historia Augusta, Oxford.

Syme, R. (1976), “Bogus Authors”, in: J. Straub (ed.) Bonner Historia-Augusta-Colloquium $1972-1974$, Bonn, 311-321.

Thomson, M. (2007), “The Original Title of the Historia Augusta", in: Historia 56/1, 121-125.

Thomson, M. (2012), Studies in the Historia Augusta, Brussels.

Van Nuffelen, P. (2017), "The Highs and Lows of Biography", in: B. Bleckmann and H. Brandt (eds.), Historia Augusta Colloquium Dusseldorpiense, Bari, 175-187.

Velaza, J. (1997), “Tacite dans l'H.A.: Vers une révision”, in: G. Bonamente and K. Rosen (eds.), Historiae Augustae colloquium Bonnense, Bari, 241-253.

White, P. (1967), “The Authorship of the Historia Augusta", in: Journal of Roman Studies 57/1-2, $115-133$. 
Zecchini, G. (1991), “La fortuna di Tacito e l'Historia Augusta”, in: G. Bonamente and N. Duval (eds.), Historiae Augustae colloquium Parisinum, Macerata, 337-350.

Zinsli, S.C. (2014), Kommentar zur Vita Heliogabali der Historia Augusta, Bonn.

Zinsli, S.C. (2017), "Fälschungs- und Erzähltechniken der Historia Augusta", in: W. Kofler and A. Novokhatko (eds.), Verleugnete Rezeption: Fälschungen antiker Texte, Freiburg im Breisgau and Vienna, 133-151. 
Fig. 1.: The HA Lives and Scriptores

Titles as in Hohl's Teubner ed., Extant lives; ostensibly lost lives (* - inferred; ** - explicitly mentioned)

\begin{tabular}{|c|c|c|c|c|c|}
\hline $\begin{array}{l}\text { Nerva }^{\star}+ \\
\text { praef }^{\star} ?\end{array}$ & ?? & $\begin{array}{l}\text { Pescennius } \\
\text { Niger }\end{array}$ & Spartianus & Decius (et fil.?)* & Pollio? \\
\hline Traianus* & ?? & $\begin{array}{l}\text { Vita Clodii } \\
\text { Albini }\end{array}$ & Capitolinus & $\begin{array}{l}\text { Gallus, Hostilianus, } \\
\text { Volusianus* }\end{array}$ & Pollio? \\
\hline De vita & Aelius & Antoninus & & & \\
\hline Hadriani & Spartianus & Caracallus & Spartianus & Aemilianus* & Pollio? \\
\hline Aelius & Spartianus & $\begin{array}{l}\text { Antoninus } \\
\text { Geta }\end{array}$ & Spartianus & Valeriani Duo (inc.) & Pollio \\
\hline $\begin{array}{l}\text { Antoninus } \\
\text { Pius }\end{array}$ & $\begin{array}{l}\text { Julius } \\
\text { Capitolinus }\end{array}$ & $\begin{array}{l}\text { Opilius } \\
\text { Macrinus }\end{array}$ & Capitolinus & Gallieni Duo & Pollio \\
\hline $\begin{array}{l}\text { Vita Marci } \\
\text { Antonini } \\
\text { Philosophi }\end{array}$ & Capitolinus & $\begin{array}{l}\text { Diadumenus } \\
\text { Antoninus }\end{array}$ & Lampridius & Tyranni Triginta & Pollio \\
\hline Verus & Capitolinus & $\begin{array}{l}\text { Antoninus } \\
\text { Heliogabalus }\end{array}$ & Lampridius & Divus Claudius & Pollio \\
\hline $\begin{array}{l}\text { Avidius } \\
\text { Cassius }\end{array}$ & $\begin{array}{l}\text { Vulcacius } \\
\text { Gallicanus } \\
\text { VC }\end{array}$ & $\begin{array}{l}\text { Alexander } \\
\text { Severus }\end{array}$ & Lampridius & Divus Aurelianus & $\begin{array}{l}\text { Flavius } \\
\text { Vopiscus } \\
\text { Syracusius }\end{array}$ \\
\hline $\begin{array}{l}\text { Commodus } \\
\text { Antoninus }\end{array}$ & $\begin{array}{l}\text { Aelius } \\
\text { Lampridius }\end{array}$ & $\begin{array}{l}\text { Maximini } \\
\text { Duo }\end{array}$ & Capitolinus & Tacitus & Vopiscus \\
\hline $\begin{array}{l}\text { Helvius } \\
\text { Pertinax }\end{array}$ & Capitolinus & $\begin{array}{l}\text { Gordiani } \\
\text { Tres }\end{array}$ & Capitolinus & Probus & Vopiscus \\
\hline $\begin{array}{l}\text { Didius } \\
\text { Julianus }\end{array}$ & Spartianus & $\begin{array}{l}\text { Maximus et } \\
\text { Balbinus }\end{array}$ & Capitolinus & $\begin{array}{l}\text { Firmus, Saturninus, Proculus } \\
\text { et Bonusus (i.e. Quadrigae } \\
\text { Tyrannorum) }\end{array}$ & Vopiscus \\
\hline Severus & Spartianus & $\begin{array}{l}\text { Phillippi } \\
\text { Duo** }\end{array}$ & $\begin{array}{l}\text { Trebellius } \\
\text { Pollio? }\end{array}$ & $\begin{array}{l}\text { Carus et Carinus et } \\
\text { Numerianus }\end{array}$ & Vopiscus \\
\hline
\end{tabular}


Fig. 2.: The Scriptores' Self-References

\begin{tabular}{|c|c|c|c|}
\hline SCRIPTOR & LIVES & DATE BY EMPEROR & EXTENT \\
\hline $\begin{array}{l}\text { Aelius } \\
\text { Spartianus }\end{array}$ & $\begin{array}{l}\text { Hadr. } \\
\text { Ael. } \\
\text { Did. Jul. } \\
\text { Sev. } \\
\text { Nig. } \\
\text { Carc. } \\
\text { Geta }\end{array}$ & $\begin{array}{l}\text { - Dedications and apostro- } \\
\text { phes to Diocletian (Ael. 1.1, } \\
\text { Sev. 20.4, Nig. 9.1) } \\
\text { - Address to Constantine } \\
\text { (Geta 1.1) }\end{array}$ & $\begin{array}{l}\text { - Omnes, qui post Caesarem } \\
\text { dictatorem, hoc est divum } \\
\text { lulium, vel Caesares vel Au- } \\
\text { gusti vel principes appellati } \\
\text { sunt [...] singulis libris ex- } \\
\text { ponere (Ael. } 7.5 \text { ) } \\
\text { - Accurate refs to own lives } \\
\text { of Sev. and Geta (Carc. 1.2, } \\
11.1 \text { ) }\end{array}$ \\
\hline $\begin{array}{l}\text { Julius } \\
\text { Capitolinus }\end{array}$ & $\begin{array}{l}\text { Ant. } \\
\text { Marc. } \\
\text { Verus } \\
\text { Pert. } \\
\text { Alb. } \\
\text { Macr. } \\
\text { Mxmn. } \\
\text { Gord. } \\
\text { Max.-Bal. }\end{array}$ & $\begin{array}{l}\text { - Apostrophes to Diocletian } \\
\text { (Marc. 19.12, Ver. 11.4, } \\
\text { Macr. 15.4) } \\
\text { - Apostrophes to Constan- } \\
\text { tine (Alb. } 4.2, \text { Mxmn. } 1.1 \text {, } \\
\text { Gord. } 34.6 \text { ) } \\
\text { - Mentioned by Vopiscus } \\
\text { (Prob. } 2.7 \text { ) }\end{array}$ & $\begin{array}{l}\text { - Refers to life of Niger not } \\
\text { in collection, extant life is by } \\
\text { Spartianus (Alb. } 1.4)\end{array}$ \\
\hline $\begin{array}{l}\text { Vulcacius } \\
\text { Gallicanus VC }\end{array}$ & Av. Cass. & $\begin{array}{l}\text { - Apostrophe to Diocletian } \\
\text { (Av. Cass. 3.3) }\end{array}$ & $\begin{array}{l}\text { - omnes, qui imperatorium } \\
\text { nomen sive iusta causa sive } \\
\text { iniusta habuerunt, in litteras } \\
\text { mittere, ut omnes purpura- } \\
\text { tos, Auguste, cognosceres } \\
\text { (Av. Cass. } 3.3 \text { ) }\end{array}$ \\
\hline
\end{tabular}

\begin{tabular}{|c|c|c|c|}
\hline $\begin{array}{l}\text { Aelius } \\
\text { Lampridius }\end{array}$ & $\begin{array}{l}\text { Comm. } \\
\text { Diad. } \\
\text { Hel. } \\
\text { Alex. }\end{array}$ & $\begin{array}{l}\text { - Apostrophes to Constan- } \\
\text { tine (Hel. 2.4, 34.1; Alex. } \\
65.1 \text { ) } \\
\text { - Mentioned by Vopiscus } \\
\text { (Prob. } 2.7 \text { ) }\end{array}$ & $\begin{array}{l}\text { - Implies has written about } \\
\text { Macrinus, extant life is by } \\
\text { Capitolinus (Diad. 6.1) } \\
\text { - Intends to write about } \\
\text { Gordiani, Alexander; Aureli- } \\
\text { an; Claudius; Diocletian; } \\
\text { Maximian; Constantine; Lici- } \\
\text { nius; Maxentius } \\
\text { (Hel. } 34-35 \text { ) } \\
\text { - Will write about Aurelian si } \\
\text { vita subpeditaverit (Alex. } \\
64.2 \text { ) }\end{array}$ \\
\hline $\begin{array}{l}\text { Trebellius } \\
\text { Pollio }\end{array}$ & $\begin{array}{l}\text { [Phil.] } \\
\text { Val. } \\
\text { Gal. } \\
\text { Trig. } \\
\text { Claud. }\end{array}$ & $\begin{array}{l}\text { - Third-person refs to Con- } \\
\text { stantius Caesar, seemingly } \\
\text { as living (Gal. } 7.1,14.3 \text {, } \\
\text { Claud. } 1.1 \text { etc.) }\end{array}$ & $\begin{array}{l}\text { - Vopiscus says wrote a du- } \\
\text { obus Philippis usque ad } \\
\text { divum Claudium et eius fra- } \\
\text { trem Quintillum imperatores } \\
\text { (Arln. 2.1) } \\
\text { - Vopiscus again praises his } \\
\text { diligentia, mentions Trig. } \\
\text { (Quadr. 1.3) }\end{array}$ \\
\hline
\end{tabular}


Fig. 2.: The Scriptores' Self-References (Continued)

\begin{tabular}{llll}
\hline SCRIPTOR & LIVES & DATE BY EMPEROR & EXTENT \\
\hline Flavius Vopiscus & Arln. & - Quotes young Diocletian's & - Identifies self as writer of \\
Syracusius & Tac. & words as from father (Arln. & lives of Aurelian, Tacitus and \\
& Prob. & 43-44) and assassination & Florian, and future author \\
& Quadr. & of Aper from grandfather & usque ad Maximianum Dio- \\
& Carus & (Carus 13.3) & cletianumque (Prob 1.5), \\
& imperator, seemingly as liv- & 2.3) \\
& ing (Arln. 44.5) & - Anticipates writing the \\
& & Carus, but no further (Prob. \\
& & 24.6-8, Quadr. 15.10, \\
& & Carus 18.5) \\
\hline
\end{tabular}


